\title{
Expansion of the Objects of State Administrative Disputes after the Enactment of Law Number 30 of 2014 Concerning Government Administration and Supreme Court Regulation Number 2 of 2019 Concerning Guidelines for the Resolution and Authority to Adjudicate Unlawful Conducts by Government Agencies or Officials (Onrechtmatige Overheidsdaad / OOD)
}

\author{
Sonyendah Retnaningsih; Disriani Latifah Soroinda Nasution; Heryna Oktaviani; Muhammad \\ Rizqi Alfarizi Ramadhan
}

Faculty of Law, The University of Indonesia (FHUI), Indonesia

http://dx.doi.org/10.18415/ijmmu.v8i1.2382

\begin{abstract}
Historically, State Administrative Court (PTUN) has existed since 1986, with the enactment of Law Number 5 of 1986 concerning State Administrative Court which currently has been amended by Law Number 9 of 2004 concerning Amendment to Law Number 5 of 1986 concerning State Administrative Court and amended again by Law Number 51 of 2009 concerning the Second Amendment to Law Number 5 of 1986 concerning State Administrative Court. The role of the Administrative Court according to the explanation of the law, the PTUN functions as a control or supervisory agency thus legal actions from government officials do not deviate, in addition to protecting the rights of citizens from the actions of officials who abuse their authority or act arbitrarily. Currently, the object of dispute and can be sued at the State Administrative Court is only a State Administration decision reduced by the exceptions stipulated in Article 2 and Article 49 of the PTUN Law. The provisions of Article 3 of the Administrative Court Law No. 5 of 1986 on negative fictitious could potentially no longer be enforced since the enactment of Article 53 of the AP Law which stipulates positive fictitious. Since the promulgation of Law Number 30 of 2014 concerning Government Administration (hereinafter referred to as AP Law) on 17 October 2014, there has been a change in the legal criteria from the government written stipulation (beschikkingen) which was initially restrictive and can be sued to the PTUN, yet it has recently become extensive (which was originally mere beschkking, currently it almost covers all variations of besluiten). With the enactment of the AP Law, there will be an expansion of absolute competence and objects of state administration disputes, as stipulated in Article 87 of the AP Law which includes: first, Government Administration Decrees, as stipulated in Article 1 point 7 of the AP Law; second, Government Administration Actions Based on Article 1 point 8 of the AP Law. Furthermore, with the enactment of the Supreme Court Regulation Number 2 of 2019 concerning Guidelines for Government Action Dispute Resolution and the Authority to Adjudicate Unlawful Conducts by Government Agencies and/or Officials (onrechtmatige overheidsdaad / OOD), the judicial power shall transfer from the General Court to the State Administrative Court. This crucial matter continues to be the groundwork and reason for conducting the current research entitled the expansion of the state administration dispute object after the enactment of
\end{abstract}


Law Number 30 of 2014 concerning Government Administration and the supreme court regulation (Perma) Number 2 of 2019 concerning Guidelines for Government Action Dispute Resolution and Authority to Adjudicate Unlawful Conducts by the Government Agencies and/or Officials (onrechtmatige overheidsdaad / OOD). Conducted through normative juridical research method, this research-based paper examined the interviews through judges at PTUN Jakarta and Bandung and the main data source within this qualitative analysis serves as the secondary data or literature data.

Keywords: Object of Disputes; Administrative Court; Decision; OOD

\section{Introduction}

A. Background of the study

The idea of administrative justice (administrative rechtspraak) comes from states that adhere to the rule of law. Administrative justice is the hallmark of a rule of law as a judicial body that can provide legal protection for citizens from the arbitrariness of the authorities. ${ }^{1}$ According to Julius Stahl, there are four (4) basic elements of formal legal states cited as follows: ${ }^{2}$

1. Protection of human rights;

2. Separation of powers;

3. Every government action must be based on statutory regulations; and

4. The existence of an independent administrative court.

The function and position of the administrative judiciary is to maintain legal protection for citizens as justice seekers and to carry out the function of judicial control over government administrative bodies or officials. This is a result of giving large power to legal state to enforce, administer and improve the welfare of its citizens, and therefore the citizens deem necessary guarantee of legal protection for the great state power. ${ }^{3}$ According to Prajudi Atmosudirdjo, the purpose of the establishment of administrative court is to develop and maintain appropriate state administration based on the rule of law or statute. ${ }^{4}$

From such illustration, according to Sjachran Basah, the purpose of administrative justice is to provide legal protection and legal certainty, not only for the people but also for the state administration by sustaining and maintaining the balance of the interests among the society and individuals. For state administration, order, peace and security shall be maintained in carrying out its duties for the creation of a strong, clean and authoritative government in a constitutional state based on Pancasila. ${ }^{5}$ Sjachran Basah also delivered his perspective that it deems required to take anticipatory stages to provide binding protection to citizens from possible violations of human rights by government officials or administrative bodies through the following actions: ${ }^{6}$

a. Exceeding the limits of authority;

b. Misusing their authority;

${ }^{1}$ Thorkis Pane, Memahami Praktek Beracara Di Peradilan Tata Usaha Negara, Jakarta: Pane Press \& Co, 2005 , p. 1.

${ }^{2}$ Hotma P. Sibuea, Asas Negara Hukum, Peraturan Kebijakan dan Asas-Asas Umum Pemerintahan Yang Baik, Jakarta: Erlangga, 2010, p. 29.

${ }^{3}$ Enrico Simanjuntak, Perdebatan Hukum Administrasi Sebuah Kompilasi Artikel Hukum Administrasi, Bekasi: Gramata Publishing, 2014, p. 3.

${ }^{4}$ S. Prajudi Atmosudirjo, Hukum Administrasi Negara, Jakarta: Ghalia Indonesia, 1977, p. 69.

${ }^{5}$ Sjachran Basah, Perlindungan Hukum Terhadap Sikap Tindak Administrasi Negara, Bandung : Alumni, 1985 , p., 25.

${ }^{6}$ Rochmat Soemitro, "Peradilan Tata Usaha Negara dan Perlindungan Hak-Hak Asasi" (presented in the National Seminar on National Law IV, BPHN, 26-30 March 1979 di Jakarta), p. 22-23. 
c. Carry out actions contrary to their duties;

d. Incorrectly applying laws or regulations;

e. Committing acts against the law (onrechtmatige overheidsdaad);

f. Take actions that are not in accordance with the regulations.

Philosophically, according to S.F. Marbun, the objective of the establishment of administrative court is to provide protection for the rights of individual and citizens, so as to achieve suitability, balance and harmony between the individual interests and public interests.7 In an attempt to achieve such considerable protection, it deems necessary a single judicial institution, known as the State Administrative Court, which can play a large role in getting access to justice.

In Law Number 48 of 2009 concerning Judicial Power, Article 18 states that the judicial power shall be implemented by a Supreme Court and four judicial bodies underneath it in the form of public courts, religious affairs courts, military tribunals, and state administrative courts. Thus, the State Administrative Courts (hereinafter referred to as PTUN) is under the authority of the Supreme Court as the highest peak of judicial power holders. The existence of PTUN was formed based on Law Number 5 of 1986 concerning State Administrative Court (hereinafter referred to as State Administrative Court Law) as amended by Law Number 9 of 2004 concerning Amendment to Law Number 5 of 1986 concerning State Administrative Court, and amended again by Law Number 51 of 2009 concerning Second Amendment to Law Number 5 of 1986 concerning State Administrative Court.

The role of PTUN according to the explanation of the PTUN law functions as a control or supervisory agency thus legal actions from government officials do not deviate, as well as protecting the rights of citizens from the actions of officials who abuse their authority or act arbitrarily. According to Paulus Effendie Lotulung, the special characteristics attached to the PTUN supervisory agency as "judicial control" are mainly described as follows: ${ }^{8}$

1. That supervision is external control, because it is carried out by an institution that is outside the power of the executive body;

2. That the supervision emphasizes more on repressive actions or what is called control a-posteriori;

3. That the supervision is based on the legal aspect of the controlled government conducts, namely the assessment of whether the action is rechtmative or violates the law.

The competence of PTUN according to Article 47 of the PTUN Law is a court that has a duty and authority to examine, decide and resolve State Administrative disputes. State Administrative Disputes according to Article 1 point 4 of the PTUN Law are described as follows:

"Disputes arising in the field of State Administration between individuals or civil legal entities with State Administrative Bodies or Officers, both at the central and regional levels, as a result of the issuance of State Administrative Decrees, including personnel disputes based on the prevailing laws and regulations".

Based on the PTUN Law, the only object of dispute and can be sued in the PTUN is currently only a State Administration decision. This is because the provisions of Article 3 of Law no. 5 of 1986 concerning the PTUN Law regarding negative fictitious cannot be reinforced since the enactment of Article 53 of the AP Law which stipulates positive fictitious, because it will create legal uncertainty about the procedures for solving legal problems that shall be implemented by the PTUN.

\footnotetext{
${ }^{7}$ S.F. Marbun, Peradilan Administrasi Negara dan Upaya Administrasi di Indonesia, Yogyakarta: UII Press, 2003 , p. 28.

8 Paulus Effendie Lotulung, "Peradilan Tata Usaha Negara Dalam Kaitannya Dengan Rechstaat Republik Indonesia, (presented in the State Law Seminar of the Republic of Indonesia, FHUI, 1991), p. 1.
} 
According to Article 1 number 3 of PTUN Law No. 5 of 1986 in conjunction with Article 1 point 9 of the Administrative Court Law No. 51 of 2009, the State Administration Decree is:

"A written stipulation issued by a State Administrative Body or Official containing legal conduct for State Administration based on the prevailing laws and regulations, such as concrete, individual and final which give rise to legal consequences for a person or civil legal entity".

In the PTUN Law, it is stated that the object of the PTUN dispute is a written decision issued by a State Administration Agency or Official, reduced by the exceptions regulated in Article 2 of the PTUN Law which regulates decisions that are not included in the object of state administration dispute. In addition, according to the provisions of Article 49 of the PTUN Law, the court is not authorized to adjudicate a state administration dispute which is issued in a state of war, a state of danger, a state of natural disaster, or an extraordinary situation that is dangerous, as well as in an urgent situation for the public interest.

In addition to that, according to the provisions of Article 49 of the PTUN Law, the court is not authorized to adjudicate a state administration dispute which is issued in a state of war, a state of danger, a state of natural disaster, or an extraordinary situation that is dangerous, as well as in an urgent situation for the public interest.

KTUN $=$ Article $1-($ Article $2+$ Article 49$)$

Based on the provision of Article 53 paragraph (1) in conjunction with Article 1 number 4 of Law Number 5 of 1986, it can be concluded that a State Administration Decree issued by State Administration Agencies or Officials can serve as the object of proceedings in a state administration dispute. ${ }^{9}$

After the reformation, several laws were promulgated specifically regulating the authority to adjudicate the state administration court on certain disputes such as: ${ }^{10}$

1). Law No. 14 of 2008 concerning The Openness of Public Information;

2). Law No. 2 of 2012 concerning Land Acquisition for Public Interest;

3). Law No. 30 of 2014 concerning Government Administration which also regulates the application for assessment of elements of abuse of authority and positive fictitious applications;

4). Law no. 20 of 2016 concerning Regional Head Elections;

5). Law no. 7 of 2017 concerning General Elections and so on.

The competence of the PTUN Law in resolving TUN disputes is still ambiguous, the reason is it still provides authority to other agencies (moot court) outside the State Administrative Court to adjudicate state administration disputes. This can be seen in Article 48 of the PTUN Law which gives authority to Administrative Bodies or Officials to resolve through administrative efforts. In relation to this matter, administrative effort is a procedure that can be taken by a person or a civil legal entity if he/she is not satisfied with a TUN decision, and the procedure is carried out within the agency concerned. In this regard, Administrative efforts consist of: ${ }^{11}$

${ }_{9}^{9}$ Sormaryono and Anna Erliyana, Tuntutan Praktek Beracara Di Peradilan Tata Usaha Negara, Jakarta: Primamedia Pustaka, 1999, p. 11.

${ }^{10}$ Sudarsono and Rabbenstain Izroiel, Petunjuk Praktis Beracara Di Peradilan Tata Usaha Negara Konven Konvensional dan

Elektronik, $1^{\text {st }}$ Ed, Jakarta: Prenadamedia Group, 2019, p. 32.

${ }^{11}$ Rozali Abdullah, Hukum Acara Peradilan Tata Usaha Negara, Jakarta: Raja Grafindo Perkasa, 1994, p. 23. 
a. Administrative objections submitted to the superior of the Official issuing the TUN Decree concerned;

b. Administrative appeals made by the superior agency or other agencies from the issuing the TUN decision concerned.

Since the promulgation of Law Number 30 of 2014 concerning Government Administration (hereinafter referred to as UUAP) on 17 October 2014, there has been a change in the legal criteria from the government written stipulation (beschikkingen) which can be sued to the PTUN, which was initially restrictive and has now become extensive (which was originally just beschkking, currently it almost covers all variations of besluiten). In substance, UUAP is type of material law, while the PTUN Law is formal law (procedural law). ${ }^{12}$ With the enactment of UUAP there is an expansion of absolute competence and objects of state administration dispute, as stated in Article 87 UUAP which stipulates that:

"With the enactment of this law, the State Administration Decree as referred to in Law Number 5 of 1986 concerning State Administrative Courts as amended by Law Number 9 of 2004 and Law Number 51 of 2009 shall be interpreted as: a written stipulation which also includes factual actions; decisions of state administrative bodies and/or officials within the executive, legislative, judiciary and other state administrators; based on statutory provisions and AAUPB; is final in a broader sense; decisions with potential legal consequences; and/or decisions that apply to members of the people."

In the PTUN Law, the formulation of State Administrative Decrees (hereinafter referred to as KTUN) as the object of the dispute contains cumulative-limitative legal criteria, it considerably suggests that strictly legal limitations or criteria whose elements cannot be reduced are required as determined in Article 1 point 3 of Law 51986 in conjunction with Article 1 point 9 of Law no. 51 of 2009 concerning State Administrative Courts.

Before the AP Law is established, a lawsuit against the government that does not meet the basic criteria for the object of the state administration dispute will be submitted as an object of dispute to the General Court on the basis of a lawsuit against the law as regulated in Article 1365 of the Civil Code, namely legal conducts committed by the authorities (onrechtmatige overheidsdaad / OOD). With the enactment of the Supreme Court Regulation No.2 of 2019 (Perma 2 of 2019 concerning Guidelines for Government Action Dispute Resolution and the Authority to Adjudicate Unlawful Conducts by Government Agencies and/or Officials (onrechtmatige overheidsdaad / OOD), and in turns, the authority to judge is transferred from the General Court to the Administrative Court. This is because the abuse of power in Indonesia is still dominated by the abuse of power that arises from the mistakes of individual officials. And therefore, in order to provide legal protection for citizens from abuse of authority committed by TUN bodies or officials, and most importantly, the delegation of authority is carried out to the PTUN specifically for cases of illegal acts by government bodies and/or government officials (onrechtmatige overheidsdaad / OOD). It has been in great demand and continues to be the basis and reason for conducting this formulated research, entitled the expansion of the state administration dispute object after the enactment of Law Number 30 of 2014 concerning Government Administration and the supreme court regulation (Perma) Number 2 of 2019 concerning Guidelines for Government Action Dispute Resolution and Authority to Adjudicate Unlawful Conducts by the Government Agencies and/or Officials (onrechtmatige overheidsdaad / OOD).

${ }^{12}$ Enrico Simantjuntak, Op. Cit., p. 564. 


\section{Research Method}

This research-based paper is type of a normative juridical research method, by looking at positive laws, both written and unwritten. This approach is designed to study and analyze problems by describing various problems in a comprehensive-integrative manner. ${ }^{13}$ The present project focuses on data contained in statutory regulations, by examining library materials, and is supported by conducting interviews with with judges at PTUN Jakarta and Bandung.

The main data source in this normative juridical research is secondary data or library data. ${ }^{14}$ The classified data is in the form of data obtained from literature studies including official documents, books, research results in the form of reports and articles in journals. Document study is a study that examines a variety of documents, both those related to laws and regulations as well as existing documents. ${ }^{15}$

In the legal literature, the data source is called legal material. Legal materials are all sources used as the law library for the purpose of analyzing applicable laws. Legal materials conducts analysis in normative legal research consists of primary, secondary and tertiary legal materials which are carried out using data collection techniques through document study and literature study. ${ }^{16}$ The three basic types of legal materials used in the present study as follows: ${ }^{17}$

1. Primary legal materials, defined as binding legal materials which consists of basic norms or rules, basic regulations, statutory regulations or jurisprudence. The legal materials used in this study include: Law Number 49 of 2009 concerning Judicial Power, Law Number 5 of 1986 concerning State Administrative Courts in conjunction with Law Number 9 of 2004 in conjunction with Law Number 51 of 2009, Law Number 30 of 2014 concerning Government Administration, Supreme Court Regulation Number 2 of 2019 concerning Guidelines for Government Action Dispute Resolution and Authority to Adjudicate Unlawful Conducts by Government Agencies and/or Officials (onrechtmatige overheidsdaad), Supreme Court circular letter (hereinafter referred to as SEMA) Number 4 of 2016 concerning Enforcement of Formulas Results of the 2016 Supreme Court Chamber Plenary Meeting as Guidelines for the Implementation of Duties for Courts, SEMA No. 2 of 2019 concerning the Enforcement of the Formulation of the Results of Plenary Meeting of the Supreme Court Chamber of 2019 as Guidelines for the Implementation of Duties for Courts and others.

2. Secondary legal materials, defined as legal materials that provide an explanation of primary legal materials such as drafts of laws and regulations, research results, works from legal circles and others. Secondary legal materials used by researchers include books and articles related to State administrative law and Administrative Law of Administrative Court.

3. Tertiary legal materials, defined as legal materials that provide instructions or explanations for primary and secondary legal materials such as dictionaries, encyclopedias, and others. The tertiary legal materials used in this study are an Indonesian dictionary and an English dictionary.

Qualitative research method is an approach that explores and understands central phenomena. ${ }^{18}$ In this study used qualitative research methods using data analysis in the form of qualitative analysis ${ }^{19}$. Whilst the data analysis method used is descriptive analytical, referred to as qualitative analysis of

${ }^{13}$ Soeryono Soekanto and Sri Mamudji, Penelitian Hukum Normatif: Suatu Tinjauan Singkat,11 ${ }^{\text {th }}$ Ed, Jakarta: Raja Grafindo Persada, 2009, p. 13.

${ }^{14}$ Ibid., p. 16.

${ }^{15}$ Ibid., p. 19.

${ }^{16}$ Soeryono Soekanto, Pengantar Penelitian Hukum, $3^{\text {rd }}$ Ed, Jakarta: UI Press, 1886, p. 12.

${ }^{17}$ Ibid., p. 52.

18 J.R. Raco, Metode Penelitian Kualitatif : Jenis, Karakteristik, dan keunggulannya, Jakarta: Grasindo, p. 5.

${ }^{19}$ Zainuddin Ali, Metode Penelitian Hukum, Cet. 3, Jakarta: Sinar Grafika, 2011, p. 107. 
secondary data. The descriptive includes the content and structure of positive law, which is an activity carried out by researchers to determine the content or meaning of legal rules used as references in solving formulated legal problems within this project. ${ }^{20}$

\section{III.Discussion}

The position of PTUN as one of the executors of judicial power is a judicial environment that is independent and separate from the General Courts, Military Courts and Religious Courts, culminating in the Supreme Court as the highest state court. The authority of PTUN according to Article 25 of Law no. 48 of 2009 concerning Judicial Power is examining, adjudicate, decide and resolve state administration disputes in accordance with the prevailing laws and regulations. The specificity of the PTUN is seen from the types of disputes being tried and the parties in litigation, known as state administration disputes in the matter of government administration law.

The development of Administrative law has led to development in the absolute competence of PTUN, both advancement based on the object of the disputes and the type of disputes. According to W. Riawan Tjandra, the development of PTUN in Indonesia when the PTUN Law was promulgated, called Law no. 5 of 1986 in conjunction with Law no. 9 of 2004 in conjunction with Law no. 51 of 2009 has absolute competence, meaning that all types of state administration disputes insofar as they meet the criteria competence of PTUN as stipulated in Article 1 point 3 of Law No. 5 of 1986 in conjunction with Article 1 point 9 of Law no. 51 of 2009 with the limitations of Article 2 and Article 48 of the Administrative Court Law is the authority of the Administrative Court. ${ }^{21}$

Absolute competence is generally notable to figure out which judicial environment has the authority to judge and arbitrate cases and decide cases among the existing judicial bodies, whether the General Courts, Religious Courts, Military Courts or TUN Courts. ${ }^{22}$ In normative juridical terms, the absolute competence of PTUN according to Article 1 number 10 of the Administrative Court Law No. 51 of 2019 is adjudicating state administration disputes that arise in the field of state administration between individuals or civil legal entities, as a result of the issuance of state administrative decisions, including employment disputes based on the prevailing laws and regulations. According to Article 50 of the PTUN Law No. 5 of 1986, the competence of PTUN at the first level is to examine, decide and resolve State Administrative Court disputes. While the PTUN competence is cited as follows: (1) examine and decide on state administration disputes at the appeal level, and (2) examine and decide on state administration disputes at the first level and the final court disputes between PTUN within their jurisdiction. Furthermore, the competence of PTUN at the Supreme Court level is adjudicating state administration disputes in the Cassation and Reconsideration stage, and as a court of second level in special TUN disputes (public information disputes, disputes related to land acquisition for the public interest and disputes in the legislative elections for members of the DPR, DPRD and DPD.

The latest development of PTUN from an absolute competence perspective has shown the affirmation of the PTUN's authority in dealing with administrative law issues between citizens and the government. This is marked by the passing of Law no. 30 of 2014 concerning Government Administration which opens up space for more comprehensive administrative legal dispute resolution by PTUN. The transformation and paradigm shift in PTUN's procedural law is very dominated and influenced by the enactment of the AP Law, besides it is influenced by the presence of various sectoral laws that influence the implementation of judicial power by the PTUN.

\footnotetext{
${ }^{20}$ ibid.

${ }^{21}$ W. Riawan Tjandra, Peradilan Tata Usaha Negara Mendorong Terwujudnya Pemerintahan yang Bersih dan Berwibawa, Yogyakarta : Universitas Atmajaya Publisher, 2009, p 1.

${ }^{22}$ Nomensen Sinamo, Peradilan Tata Usaha Negara, ${ }^{\text {st }}$ Ed, Jakarta : Jala Permata Aksara, 2017, p. 43.
} 
The formal source of legal proceedings for PTUN is the positive legal provisions governing the Administrative Procedure Law. The procedural law in PTUN is regulated in the PTUN Law, namely in Chapter III of the PTUN Law starting from Article 47 to Article 132, which of these provisions can be categorized into groups Conventional PTUN Procedure Law as a negation of the special PTUN Procedure Law which is regulated in sectoral / organic statutory regulations. In addition, a number of jurisprudence has also enriched the treasury of the Administrative Court Procedure.

Besides the PTUN Law and jurisprudence, there are several other laws related to the authority of the PTUN. Some of the laws that are the source of formal law in the proceedings at PTUN include:

1. Law no. 48 of 2009 concerning Judicial Power;

2. Law no. 14 of 1985 in conjunction with Law no. 3 of 2009 concerning the Supreme Court;

3. Law no. 14 of 2008 concerning Openness of Public Information;

4. Law. No. 25 of 2008 concerning Public Services;

5. Law NO. 32 of 2009 concerning Protection and Management of the Environment;

6. Law no. 2 of 2012 concerning Land Acquisition for Development for Public Interest;

7. Law no. 8 of 2012 concerning the General Election of DPR, DPD and DPRD members as amended by law. No. 7 of 2017 concerning General Elections;

8. Law no. 37 of 2014 concerning Soil and Water Conservation;

9. Law no. 30 of 2014 concerning Government Administration;

10. Law no. 8 of 2015 concerning Regional Head Elections and others.

At each piece of law within a legal and regulatory framework, there are a number of laws referred as the source of formal law in the proceedings at PTUN, including:

1) Perma No. 2 of 2011 concerning Procedures for KIP Dispute Resolution in Courts;

2) Perma No. 3 of 2015 concerning Special Judges for Election State Administration Disputes;

3) Perma No. 4 of 2015 concerning Guidelines for Procedures in Abuse of Authority;

4) Perma No. 5 of 2015 concerning Procedure Guidelines for Obtaining Decisions on Acceptance of Applications to Obtain Decisions and/or Actions of Government Agencies or Officials as amended in Perma No. 8 of 2017 concerning Guidelines for Procedures to Obtain Decisions on Acceptance of Applications to Obtain Decisions and/or Government Officials;

5) Perma No. 2 of 2016 concerning Procedures for Procedure Guidelines in Dispute Determination of Development Locations for Public Interest in PTUN;

6) Perma No. 5 of 2017 concerning Procedures for Election Process Dispute Resolution in State Administrative Courts;

7) Perma No. 6 of 2017 concerning Special Judges in Election Process Disputes at the State Administration Court;

8) Perma No. 11 of 2016 concerning Procedures for the Resolution of Electoral State Administrative Disputes and Election Administration Disputes.

9) Perma No. 1 of 2019 concerning the Administration of Cases and Trials in Court Electronically;

10) Perma No. 2 of 2019 Guidelines for the Resolution and Authority to Adjudicate Offenses of Law by Government Agencies or Officials (Onrechtmatige Overheidsdaad)

11) Supreme Court circular letter (hereinafter referred as to SEMA) No. 4 of 2016 concerning the Enforcement of the Formulation of the Plenary Meeting Results of the Supreme Court Chamber of 2015 as Guidelines for the Implementation of Duties for the Court.

12) SEMA No. 1 of 2017 concerning the Enforcement of the Formulation of the Plenary Meeting Results of the Supreme Court Chamber of 2017 as Guidelines for the Implementation of Duties for the Court. 
13) SEMA No. 2 of 2019 concerning the Enforcement of the Formulation of the Plenary Meeting Results of the Supreme Court Chamber of 2019 as Guidelines for Implementing Tasks for the Court.

In addition to statutory regulations and the jurispudence of the Supreme Court, it is also necessary to pay attention to several decisions of the Constitutional Court which are also the source of the Administrative Procedure Law, including:

a. The Constitutional Court Decision No. 17 / PUU-IX / 2011. Based on this decision, the provisions of Article 109 paragraph (3) of the PTUN Law do not have binding legal force;

b. The Constitutional Court Decision No. 31 / PUU-XI / 2013. Based on this decision, DKPP can be seated as the legal subject of the Defendant in PTUN;

c. The Constitutional Court Decision No. 77 / PUU-IX / 2011. Based on this decision, BUMN Bank receivables are not state receivables, therefore the settlement is not to the State Receivables Affairs Committee;

d. The Constitutional Court Decision No. 25 / PUU-XIV / 2016 confirms the limits of administrative and criminal liability, as referred to in UUAP and other legislative policies, and so on.

PTUN Law No. 5 of 1986 does not explicitly state what is the object of the dispute in the PTUN. But conventionally, the criteria for the object of state administration disputes are the State Administrative Decree as regulated in Article 1 number 3 of the Administrative Court Law No. 5 of 1986 in conjunction with Article 1 number 9 of Law No. 51 of 2009. However, not all state administrative decisions (state administrative decisions) can be the object of a state administration dispute in the administrative court This is because there are restrictions (restrictions) or exceptions that determine whether a State Administrative Court can be the object of a state administration dispute. The PTUN Law stipulates the exception to state administrative decisions as an object of state administration dispute in Article 2, Article 48, Article 49 and Article 142 of the PTUN Law, besides developing in various jurisprudences and the influence of various other legal products. Thus, it can be said that although TUN bodies and / or officials can be sued at the PTUN, not all legal actions can be tried by the PTUN due to the limitations and exceptions.

The expansion of the object of state administration disputes at this time associated with the enactment of the AP Law has brought a big explosion in changing the meaning of decisions as objects of state administration disputes. With the enactment of the AP Law, a wider range of objects that can be objects of state administration disputes and can be sued at the PTUN include:

1. Government Administration Decisions, as regulated in Article 1 point 7 of the AP Law, namely Government Administration Decisions or also known as State Administrative Decisions, are written decrees issued by government agencies and / or officials in the administration of government.

Furthermore, the meaning of state administrative decisions in Article 87 of the AP Law has had an influence on the meaning of the scope of the state administration dispute object, so that state administrative decisions in the State Administrative Court Law must be interpreted as follows:

a) A written determination that includes factual action;

b) Decisions of state administration agencies and / or officials in the executive, legislative, judicial and other state administrations;

c) Based on statutory regulations and General Principles of Good Governance (AUPB);

d) is final in a broad sense;

e) Decisions with potential legal consequences;

f) Decisions that apply to the community. 
The following will explain some of the elements contained in Article 87 of the AP Law:

a. Written decisions that include factual actions.

A written stipulation refers to the content of the legal relationship stipulated in the decision concerned, which can be in the form of: obligations to do or not do something or to allow something, granting a subsidy or assistance, granting a license or giving a status. ${ }^{23}$ Pursuant to Article 38 of the AP Act, officials and / or governing bodies may make decisions in the form of electoral law that have the same force as written decisions. If there is a difference between a decision in electronic form and a decision in written form, then what happens is a decision in written form. ${ }^{24}$ Meanwhile, factual action according to Enrico Simanjuntak must be interpreted as administrative action, because factual action is a species of the genus of administrative action. ${ }^{25}$ According to MARI jurisprudence No. 144K / TUN / 1998 dated September 29, 1999, in its legal terms, it is stated that demolition is carried out without prior order / notification, so the demolition is factual. ${ }^{26}$

b. Decisions of state administration bodies and / or officials in the executive, legislative, judicial and other state administrations, the meaning of which are decisions issued by government agencies and / or officials who carry out government functions both within the government and other state administrators as regulated in Article 1 point 3 UUAP. Meanwhile, the government function according to Article 1 point 2 of the AP Law is a function in carrying out government administration which includes the functions of regulating, serving, governance, which is the administration in making decisions and / or actions by government agencies and / or officials.

c. Decisions that apply to members of the community.

The definition of a decision that applies to the community is not meant as a general decision that is identical to regulation or legislation. Based on SEMA No. 14 of 2016, the object of the lawsuit and / or application that is not included in the authority of the Administrative Court are decisions and / or actions that are general-abstract in nature. ${ }^{27}$ Thus, the definition of community members in Article 87 UUAP must be seen in the context as referred to in Article 1 number 15 UUAP, namely that a citizen is a person or a civil legal entity related to decisions and / or actions. In Article 40 of the AP Law, it is stated that the parties to the Government Administration procedure consist of:

1) Government Agencies and / or Officials and

2) Community members as applicants or related parties.

Expansion of access to justice, in Article 87 letter f UUAP, namely decisions that apply to citizens, in practice it has often occurred, namely that an object of dispute is addressed to citizens in a location without mentioning the individuals. For example, a decree regarding the demolition of houses along street $\mathrm{X}$ in city $\mathrm{Y}$. Although the individual houses along street $\mathrm{X}$ in town $\mathrm{Y}$ are not identified as individuals, it can actually be determined who is affected by the decision. ${ }^{28}$

\footnotetext{
${ }^{23}$ Indroharto, Usaha Memahami Undang-Undang tentang Peradilan Tata Usaha Negara, Buku I, Jakarta : Pustaka Sinar Harapan, 2004, p. 164.

${ }^{24}$ Tri Cahya Indra Permana, Catatan Kritis terhadap Perluasan Kewenangan Mengadili Peradilan Tata Usaha Negara, $1^{\text {st }}$ Ed, Yogyakarta : Genta Press, 2016, p. 40.

${ }^{25}$ Enrico Simanjuntak, Op. Cit., p. 85.

${ }^{26}$ Tri Cahya Indra Permana, Op. Cit., p 40-41.

${ }^{27}$ Tri Cahya Indra Permana, Refleksi Perkembangan Hukum Administrasi Indonesia, $1^{\text {st }}$ Ed, Bandar Lampung: Pusaka Media, 2017, p. 123.

${ }^{28}$ Tri Cahya Indra Permana, Op. Cit., p. 45.
} 


\section{d. Final in a broad sense}

In the PTUN Law, it is determined that state administrative decisions that can be objects of state administration disputes must meet material requirements, namely concrete, individual and final in nature. State administrative decisions which are final means that the TUN decision is definitive, not tentative, and does not require further approval, so it can be implemented by the official who issued it. On the other hand, state administrative decisions which are still in the form of proposals or plans cannot be said to have a final character, because they still require approval from the authorized parties. Meanwhile, in the provisions of Article 87 of the AP Law, the final meaning is given a broad meaning. The provisions of Article 87 of the AP Law do not further explain what is meant by final in a broad sense. In the elucidation of Article 87 letter d of the AP Law it only states that what is meant by "final in a broad sense" includes decisions taken over by a competent superior official. In practice, it is rare to find a decision taken over by a superior official to be the object of a dispute, in fact what is often encountered is a chain decision, in which a decision must be followed up and becomes a condition for the issuance of another decision. For example, to obtain a driving license you must have a KTP. Thus, each decision is final although it can still be followed up with the next decision. ${ }^{29}$

\section{e. Decisions with potential legal consequences}

Based on the PTUN Law, the State Administrative Court which is the object of state administration dispute is the State Administrative Court which has legal consequences for a person and / or a civil legal entity. However, in UUAP, state administrative decisions which can be the object of state administration disputes apart from being final in a broad sense also have the potential to have legal consequences. According to Yodi M. Martono, the PTUN lawsuit can now be based on potential losses. The measure of potential legal consequences must at least be interpreted by the possibility of a decision to harm a person or a civil legal entity. For this reason, there is no need for losses to occur, it is sufficient to explain the possibility of any loss that can be used as the interest of a person or civil legal entity being injured.$^{30}$ From a juridical point of view, the phrase "potentially" creates legal uncertainty because it is difficult for both the parties and the judge to prove it. Casuistically, it could be that a decision has the potential to have legal consequences that can be ascertained legal consequences, for example a regent / representative's permit for a legal entity to stockpile / fill a location could potentially result in legal consequences of flooding in another location. so that parties who occupy other locations can file a lawsuit to the State Administrative Court on the basis of the object of the state administration dispute in the form of a decision on the object of the dispute which has the potential to cause legal consequences of flooding on the affected person or community. ${ }^{31}$ In SEMA No. 4 of 2016 also emphasized that one of the disputes in the PTUN includes TUN decisions and / or actions that have the potential to cause legal consequences, for example: BPKP Audit Results Report.

Along with the paradigm shift in PTUN proceedings which is confirmed by the Supreme Court policy after the enactment of the AP Law, the competence of PTUN is: ${ }^{32}$

1) Have the authority to hear cases in the form of lawsuits and applications;

2) Authorized to adjudicate unlawful acts by government power holders (government agencies and or officials) called Onrechtmatige Overheidsdaad / OOD.

3) State administrative decisions that have been examined and decided by means of an administrative appeal fall under the authority of the State Administrative Court.

\footnotetext{
${ }^{29}$ Tri Cahya Indra Permana, Op. Cit., p. 42.

${ }^{30}$ Yodi Martono Wahyunadi, Kompetensi Absolut Pengadilan Tata Usaha Negara dalam Konteks Undang-Undang Nomor 30 Tahun 2014 tentang Administrasi Pemerintahan, (Ringkasan Disertasi, Jakarta: Program Pascasarjana, Doktor Ilmu Hukum, Universitas Trisakti), 2016, p. 76.

${ }^{31}$ Tri Cahya Indra Permana, Op. Cit, p. 45.

${ }^{32}$ Enrico Simanjuntak, Op. Cit, p. 81-82.
} 
Based on SEMA No. 4 of 2016 has determined that the object of state administration dispute includes: ${ }^{33}$

a. All decisions that are:

- Concrete-individual, examples of building permit decisions;

- Abstract-individual, examples of decisions about the terms of granting permits;

- Concrete-general, for example decisions on establishing general regional minimums.

b. State Administrative Decrees and / or actions that are final in a broad sense, namely TUN decisions that have resulted in legal consequences even though they still require approval from superior agencies or other agencies, for example: environmental permits, licensing for investment facilities by BKPM.

c. TUN decisions and / or actions that have the potential to cause legal consequences, for example: LHP BPKP.

According to Dani Elfah, the concept of the decision in Article 1 point 7 of the AP Law has overturned the TUN concept as has been adopted in Article 1 point 3 of the PTUN Law No. 5 of 1986 in conjunction with Article 1 point 9 of the Administrative Court Law No. 51 of 2009. Decisions are not only concrete-individual in character, but multicaracter, namely abstract-individual and general concrete. Through Article 1 point 7 of the AP Law, the PTUN system, which was originally a super special PTUN, has shifted to a PTUN system that can examine and test all actions of government agencies and / or officials including concrete actions / factual-individual abstract and general-concrete. ${ }^{34}$

\section{Government Administration Actions}

In the theory of Government Administration Law, government actions can be classified into legal actions (rechtshandeling) and factual / material actions (Materielehandeling). Government legal action is an action taken by the government which is based on certain legal norms and is intended to cause legal consequences in certain areas of law. Meanwhile, factual / material government actions are actions taken by the government in order to serve the factual / material needs of the people and are not intended to cause legal consequences. ${ }^{35}$

There are 2 (two) forms of actions or acts of the Agency and / or TUN Officers in carrying out government functions (bestuurfunctie), described as follows: ${ }^{36}$

1. Actions based on law (rechtshandeling) can be interpreted as actions which by their nature can give rise to certain legal consequences to create rights and obligations. The action was born as a logical consequence in the position of the government as a legal subject, so that the legal action he took had legal consequences,

2. Actions based on facts / real or not based on law (feitelijkehandeling) are government actions that have no direct relationship with its authority and do not cause legal consequences.

Based on Article 1 point 8 of the AP Law, it is stated that government administration actions are actions of government officials or other state administrators to carry out and / or not take concrete actions in the context of government administration.. The three elements of action contained in the aforementioned provisions, namely (1) actions of government officials or other state administrators; (2) doing and / or not taking concrete actions; (3) in the framework of running the government. These three elements must be fulfilled cumulatively to be able to be called action and can be sued in the PTUN.

\footnotetext{
${ }^{33}$ Sudarsono dan Rabbenstain Izroiel, Op. Cit., p. 29-30.

${ }^{34}$ Dani Elfah, Keputusan dan Tindakan Administrasi Pemerintahan, (unpublished paper), p. 54.

${ }^{35}$ W. Riawan Tjandra, Hukum Administrasi Negara, $1^{\text {st }}$ Ed, Jakarta: Sinar Grafika, 2018, p. 145

${ }^{36}$ Teguh Satya Bhakti, Pembangunan Hukum Administrasi Negara Melalui Pemberdayaan Yurisprudensi Peradilan Tata Usaha Negara, Bandung: Alumni, 2018, p. 108.
} 
The competence of PTUN in the form of state administrative decisions that have been examined and decided through an administrative appeal, namely administrative objections and appeals, has been regulated both in the PTUN Law, the State Civil Apparatus Law and the AP Law. Adressat for filing an objection is submitted to the official issuing the decision, while administrative appeal is submitted to the superior of the official issuing the decision or other agency.

However, the process leading to a lawsuit between the PTUN Law and the AP Law is slightly different. According to the PTUN Law, based on Article 48, if a dispute resolution requires administrative efforts, all such administrative efforts must be taken first. The authority of the PTUN to examine disputes only arises when all available administrative measures have been taken by the community members. Meanwhile, according to Article 75 paragraph (1) of the AP Law, it is stated that members of the community who are disadvantaged by decisions and / or actions can submit administrative efforts to government officials or superior officials who determine and / or carry out decisions and / or actions.

The meaning of the word "can" in Article 75 paragraph (1) of the AP Law is an addresat norm, which means that a person may not exercise his right to file an administrative effort because he accepts the decision and / or action, but when the person concerned will file a lawsuit to the Administrative Court administrative availability remains mandatory to be followed first. In connection with the provisions of Article 129 of Law Number 5 of 2014 concerning State Civil Servants (ASN Law), administrative efforts must be taken by Civil Servants who object to decisions and / or actions of government officials or agencies. $^{37}$

Another difference regarding the regulation regarding administrative efforts in the PTUN Law and the AP Law is that the result of public dissatisfaction with the settlement of administrative appeals made by the community becomes the authority of PT TUN based on Article 51 paragraph (3) of the PTUN Law. Meanwhile, according to Article 76 paragraph (3) of the AP Law, in the event that the community members do not accept the settlement of the appeal by a superior official, then the community members can file a lawsuit at the PTUN. The impact on the community is of course causing the lengthy process of litigation in the State Administrative Court to objections, administrative appeals, PTUN, PT TUN and the Supreme Court, this is contradicting the spirit of the AP Law to accelerate society to obtain justice, certainty and legal benefits. ${ }^{38}$

Types of government actions that can be the object of a dispute in the PTUN, based on Perma No. 2 of 2019 concerning Guidelines for Government Action Dispute Resolution and Authority to Adjudicate Unlawful Acts by Government Agencies and / or Officials (Onrechtmatige Overheidsdaad / OOD), there are 2 (two) types of disputes related to government actions, namely:

1. a government action dispute is a dispute that arises in the field of government administration between citizens and government officials or other state officials as a result of government action.

2. a dispute of unlawful acts by a body and / or government official (onrechtmatige overheidsdaad / OOD), is a dispute in which it contains a claim to declare invalid / or invalidate the action of a government official, or has no legal force binding and compensation legislation.

Based on the description above, with the enactment of the AP Law, the authority of the PTUN has been expanded, which has previously been expanded through sectoral laws, namely:

1) Disputes on Public Information Disclosure have the legal basis of Law no. 14 of 2008 and Perma No. 2 of 2011 ;

\footnotetext{
${ }^{37}$ Tri Cahya Indra Permana, Op. Cit, p. 6-7.

${ }^{38}$ Ibid., p. 10.
} 
2) Election TUN disputes consisting of Legislative Elections and Pemilukada are based on Law no. 8 of 2012 and Perma No. 6 of 2012, Law no. 1 of 2015 in conjunction with Law no. 8 of 2015;

3) Employment Disputes in the form of Disrespectful Dismissal (PTDH) and dismissal with respect not at their own request, the legal basis is Article 48 in conjunction with Article 51 paragraph (3) of the PTUN Law in conjunction with PP No. 24 of 2011;

4) Land acquisition disputes for development in the public interest are based on Law no. 2 of 2012 jo Perma No. 2 of 2016;

5) Disputes over the Fictitious Positive decision have the legal basis of Law no. 30 of 2014 and Perma No. 5 of 2015;

6) Dispute Trial Request on abuse of authority as its legal basis Law no. 30 of 2014 and Perma No. 4 of 2015

7) Public Service Disputes have the legal basis of Law no. 25 of 2009 concerning Public Services.

8) Disputes over state administrative decisions containing administrative sanctions for violations of environmental permits are based on Law no. 32 of 2009 concerning Protection and Management of the Environment and others.

Before the reformation, the procedural law that applies in PTUN is only ordinary procedures, fast procedures and short procedures which are commonly called general TUN disputes. After the reformation, there were many legislations that resulted in changes in material law (government administration law) which resulted in changes in formal procedural law arrangements (administrative procedural law / TUN) Thus, case examination apart from ordinary events, fast events and short events as regulated in the special procedural law in examining certain TUN disputes which based on organic legislation are commonly referred to as special TUN disputes.

The arrangements regarding special TUN disputes are as follows:

1. Positive Fictitious, based on Article 53 of the AP Law, the PTUN has the authority to examine the request either from a person or legal entity to obtain decisions and / or actions from government agencies or officials. According to Perma No. 8 of 2017, a positive fictitious petition is a request that is submitted in writing to ptun in the event that the application is deemed granted legally because government agencies and / or officials do not make decisions and / or take action. As for the object in the positive fictional application is the obligation of the body and / or government officials to determine the decision and / or perform the administrative action of the government applied in accordance with the applicable laws and regulations. According to Article 3 of Perma No. 8 of 2017 which does not include positive fictional applications are:

a. petition against the implementation of a court decision that has permanent legal force;

b. application for legal issues that have already been filed a lawsuit.

Based on Article 53 of the AP Law, it is associated with the status of Article 3 of the Administrative Court Law No. 5 of 1985, the Supreme Court as the highest court and constitutionally as the guardian of the implementation of legal unity in the courts below, issued a policy that could be interpreted as an affirmation that after the enactment of a positive fictitious regime, the negative fictitious regime in the PTUN Law was no longer valid.

According to SEMA No. 1 of 2017 concerning the Enforcement of the Formulation of the Plenary Meeting Results of the Supreme Court Chamber of 2017 as Guidelines for the Implementation of Duties for Courts, it states that between a positive fictitious petition and a negative fictitious claim, the following provisions apply: ${ }^{39}$

${ }^{39}$ Enrico Simantjuntak, Op. Cit, p. 147. 
a) Based on the provisions of Article 53 of the AP Law which regulates positive fictitious applications, the provisions of Article 3 of Law no. 5 of 1986 regarding the negative fictitious lawsuit can no longer be enforced, because it will create legal uncertainty regarding the procedures for resolving legal problems that must be applied by the PTUN.

b) Therefore, the provisions of Article 53 of the AP Law and Article 3 of the PTUN Law No. 5 of 1986 stipulates the similar legal issues, namely the procedures for obtaining legal protection for citizens to obtain decisions from government officials, and also in order to encourage the performance of the bureaucracy to provide excellent service, on the basis of the principle of lex posteriori derogat lex priori, then what is enforced is positive fictitious as regulated in Perma No. 8 of 2017 as a substitute for Perma No. 5 of 2015.

2. Application for assessment of elements of abuse of power. According to Article 21 of the AP Law, the PTUN has the authority to examine requests for assessment of elements of abuse of power. based on Perma No. 4 of 2015, a request for assessment of the element of abuse of power is a request submitted in writing to PTUN to assess whether or not there is an element of abuse of power carried out by government agencies and / or officials in decisions and / or actions. There are 2 (two) criteria that become the requirements for the application, namely:

a. prior to criminal proceedings;

b. after the results of supervision by the government internal supervisory apparatus (APIP).

The Petitioner is a government agency and / or official who feels that his interests have been harmed by the results of supervision by the government internal control apparatus. Meanwhile, the object of e petition is the decision and / or action of the government official being requested for assessment.

3. Public information disputes. According to Law no. 14 of 2008 concerning Openness of Public Information and Perma No. 2 of 2011 concerning Procedures for Resolving Public Information Disputes in Court, a lawsuit is an objection filed by one or the parties which in writing states that they do not accept the decision of the information commission, namely the non-litigation adjudication decision issued by the information commission regarding the dispute between public agencies and requesters for public information as regulated in Article 35 paragraph (1) of the KIP Law. The State Administration Court has the authority to adjudicate disputes submitted by state public bodies and / or requesters of information requesting information from state public bodies, namely the executive, legislative and judiciary bodies and other bodies whose functions and main duties are related to state administration, most or all of the funds originate from the APBN and / or APBD. And the parties in litigation in public information disputes at the PTUN are parties that originally disputed the information commission, namely requesters for information with state public agencies.

4. A dispute over the determination of the construction location for the public interest.

Article 23 Law no. 2 of 2012 concerning Land Acquisition for Development for Public Interest authorizes PTUN to examine disputes over the determination of development locations for the public interest. In Perma No. 2 of 2016 on Guidelines for Proceeding in Disputes on Determination of Development Locations for Public Interest in the State Administration Court, lawsuit is a written objection to the location determination submitted by the plaintiff to court. Referred to as location determination is the determination of the construction location for the public interest which is determined by a governor or regent / mayor decree receiving a delegation from the Governor, which is used as a permit for land acquisition, change in land use, and transfer of land rights in land acquisition for development for the public interest.

5. Dispute election process. Article 470 paragraph (1) of Law no. 7 of 2017 concerning General Election authorizes the PTUN to examine the procedures for the general election process. According to Perma No. 5 of 2017 concerning Procedures for Dispute Resolution in the General Election Process at PTUN, 
the object of dispute in the dispute over the general election process at PTUN is the KPU decision regarding political parties participating in the election, the KPU decision regarding the presidential and vice presidential candidate pairs, the KPU / KPU Provincial and KPU decisions Regency / City regarding permanent candidates for members of DPR, DPD, Provincial DPRD and Regency / City DPRPD.

6. Election disputes to the regions. Articles 153 and 154 of Law no. 10 of 2016 concerning the Second Amendment to Law no. 1 of 2015 concerning Perpu No. 1 of 2014 concerning the Election of Governors, Regents and Mayors Becoming Law has given the authority to PTUN to examine disputes in the election process for Governors, Regents and Mayors. Furthermore, the Supreme Court issued Perma No. 11 of 2016 concerning Procedures for Settlement of Electoral State Administrative Disputes and Election Administration Disputes Violation.

7. Public Service Disputes. In Article 51 of Law no. 25/2009 concerning Public Services states that the public can sue the organizers or implementers through PTUN if the services provided cause losses in the field of state administration.

8. Disputes over state administrative decisions containing administrative sanctions for violations of environmental permits.

In Article 76 paragraph (2) of the PPLH Law, it is stated that a civil society legal entity or person feels aggrieved by the issuance of state administrative decisions which contain administrative sanctions to sue officials who issue ktun to PTUN. In Article 93 of the PPLH Law, it is stated that everyone can file a lawsuit against ktun that meets the provisions of Article 93 paragraph (1) of the PPLH Law and others.

\section{Conclusion}

According to the PTUN Law, the object of the PTUN dispute is in form of a written decision issued by the TUN Agency, less with the exceptions set out in Article 2 of the PTUN Law which governs decisions that are not included in the TUN dispute object, and the provisions of Article 49 of the PTUN Law governing the courts not authorized to adjudicate a TUN dispute issued in a state of war, state of danger, state of natural disaster, or extraordinary hazardous situation, as well as in a state of urgency for the public interest. Based on the provisions of Article 53 paragraph (1) in conjunction with Article 1 point 4 of Law Number 5 of 1986, it can be concluded that what can be used as the object of a lawsuit in a state administration dispute is a State Administration Decree issued by a State Administration Agency and/or government officials. Since the promulgation of Law Number 30 of 2014 concerning Government Administration on October 17, 2014, There has been a change in the legal criteria from the government written stipulation (beschikkingen) that can be sued to the PTUN, which was initially restrictive to now extensive (which was originally just beschkking yet currently it almost covers all variations of besluiten). With the enactment of UUAP there has been an expansion of absolute competence and the object of state administration disputes, as regulated in Article 87 of the AP Law. The expansion of the object of state administration disputes currently associated with the enactment of the AP Law has brought about major changes in the meaning of decisions as objects of state administration disputes. With the enactment of the AP Law, the broader objects that can be objects of state administration disputes and can be sued in PTUN include: 1. Government Administration Decisions, as regulated in Article 1 point 7 of the AP Law; 2. Government Administration Actions Based on Article 1 point 8 of the AP Law. Thus, after the enactment of the AP Law, the authority of PTUN in examining, deciding and resolving state administration disputes in Indonesia has become broader, among the formal or procedural law and the substantial aspects of the judicial process. 


\section{References}

Abdullah, Rozali. Hukum Acara Peradilan Tata Usaha Negara. Jakarta: RajaGrafindo Perkasa. 1994.

Ali, Zainuddin. Metode Penelitian Hukum. 3rd Ed. Jakarta: Sinar Grafika. 2011.

Atmosudirjo, S. Prajudi. Hukum Administrasi Negara. Jakarta : Ghalia Indonesia. 1977.

Bhakti, Teguh Satya. Pembangunan Hukum Administrasi Negara Melalui Pemberdayaan Yurisprudensi Peradilan Tata Usaha Negara. Bandung : Alumni. 2018.

Basah, Sjachran. Perlindungan Hukum Terhadap Sikap Tindak Administrasi Negara. Bandung: Alumni. 1985.

Elfah, Dani. Keputusan dan Tindakan Administrasi Pemerintahan. (not publish).

Indroharto. Usaha Memahami Undang-Undang tentang Peradilan Tata Usaha Negara, Buku I. Jakarta: Pustaka Sinar Harapan. 2004.

Lotulung, Paulus Effendie. Peradilan Tata Usaha Negara Dalam Kaitannya Dengan Rechstaat Republik Indonesia, (presented at on State Law of the Republic of Indonesia Conference, FHUI, 1991).

Marbun, S.F. Peradilan Administrasi Negara dan Upaya Administrasi di Indonesia. Yogyakarta: UII Press. 2003.

Pane, Thorkis. Memahami Praktek Beracara Di Peradilan Tata Usaha Negara. Jakarta: Pane Press \& Co. 2005.

Permana, Tri Cahya Indra. Catatan Kritis terhadap Perluasan Kewenangan Mengadili Peradilan Tata Usaha Negara. 1st Ed. Yogyakarta : Genta Press,.2016. . Refleksi Perkembangan Hukum Administrasi Indonesia. 1st Ed. Bandar Lampung : Pusaka Media. 2017.

Raco, J.R. Metode Penelitian Kualitatif : Jenis, Karakteristik, dan keunggulannya. Jakarta: Grasindo.

Sibuea, Hotma P. Asas Negara Hukum, Peraturan Kebijakan dan Asas-Asas Umum Pemerintahan Yang Baik,.Jakarta : Erlangga. 2010.

Sinamo, Nomensen. Peradilan Tata Usaha Negara. 1st Ed. Jakarta: Jala Permata Aksara, 2017.

Simanjuntak, Enrico. Perdebatan Hukum Administrasi Sebuah Kompilasi Artikel Hukum Administrasi, Bekasi : Gramata Publishing. 2014.

Soekanto, Soeryono, dan Sri Mamudji. Penelitian Hukum Normatif: Suatu Tinjauan Singkat. 11th Ed. Jakarta: Raja Grafindo Persada. 2009.

Soekanto, Soeryono. Pengantar Penelitian Hukum. 3rd Ed. Jakarta: UI Press. 1886.

Soemitro, Rochmat. Peradilan Tata Usaha Negara dan Perlindungan Hak-Hak Asasi. (Presented at the National Seminar on National Law IV, BPHN, 26-30 March 1979 in Jakarta).

Sormaryono dan Anna Erliyana. Tuntutan Praktek Beracara Di Peradilan Tata Usaha Negara, Jakarta : Primamedia Pustaka. 1999.

Sudarsono dan Rabbenstain Izroiel. Petunjuk Praktis Beracara Di Peradilan Tata Usaha Negara Konvensional dan Elektronik. 1st Ed. Jakarta : Prenadamedia Group. 2019.

Tjandra, W. Riawan. Hukum Administrasi Negara. 1st Ed. Jakarta : Sinar Grafika. 2018.

W. Riawan Tjandra. Peradilan Tata Usaha Negara Mendorong Terwujudnya Pemerintahan yang Bersih dan Berwibawa. Yogyakarta : Universitas Atmajaya Publisher. 2009.

Wahyunadi ,Yodi Martono. Kompetensi Absolut Pengadilan Tata Usaha Negara dalam Konteks UndangUndang Nomor 30 Tahun 2014 tentang Administrasi Pemerintahan.(Dissertation Summary. Jakarta: Postgraduate Program, Doctor of Law, Trisakti University). 2016.

\section{Copyrights}

Copyright for this article is retained by the author(s), with first publication rights granted to the journal.

This is an open-access article distributed under the terms and conditions of the Creative Commons Attribution license (http://creativecommons.org/licenses/by/4.0/). 